\title{
Environmental Accounting Cultural Insights: A Learning From Indigenous Peoples
}

\author{
$1^{\text {st }}$ Verawaty Verawaty \\ Universitas Muhammadiyah \\ Bandung/STIE Muhammadiyah \\ Bandung \\ Indonesia \\ verariostar@gmail.com \\ $4^{\text {th }}$ Abin Surasa \\ Universitas Muhammadiyah \\ Bandung/STIE Muhammadiyah \\ Bandung \\ Indonesia
}

\author{
$2^{\text {nd }}$ Rustandi Rustandi \\ Universitas Muhammadiyah \\ Bandung/STIE Muhammadiyah \\ Bandung \\ Indonesia
}

\author{
$3^{\text {rd }}$ Erfan Erfiansyah \\ Universitas Muhammadiyah \\ Bandung/STIE Muhammadiyah \\ Bandung \\ Indonesia
}

\begin{abstract}
The purpose of this study is to explore environmental accounting from the perspective of cultural insights by exploring the role of the environment in the culture of indigenous peoples in Kampung Pulo, Garut. Phenomenology paradigm as a research method with traditional leaders (Pakuncen) and community members as informants. The results found a taboo culture that forbids raising four-legged animals. This means that all members of indigenous peoples must protect the environment for balance. A lesson that environmental accounting practices emphasize the formation of a culture of society to care for the environment. The culture of caring for the environment has an impact on sustainability.
\end{abstract}

Keywords - environmental accounting, indigenous peoples, phenomenology, taboo, sustainability

\section{INTRODUCTION}

The research entitled "Building Environmental Accounting Based on Cultural Insights: The Perspective of the Culture of Indigenous Peoples in Kampung Pulo" is inspired by the culture of indigenous peoples who are able to guarantee environmental sustainability. While environmental accounting has not yet paid attention to the local culture. Several studies on culture and the environment are closely related and create added value for environmental sustainability.

According to Oren Lyons, the philosophy of life says that all life is the same. Life does not belong to individuals, life belongs to all living things. The key word is "respect". All must respect each other. When someone does not respect the earth, he is the destroyer of the earth. When someone does not respect such as self respect, then he is a predator (Gallhofer, Gibson, Haslam, McNicholas, \& Takiari, 2000).
The predator character emerges in the world of business and economics which is only oriented to profit and prosperity of the capital owners alone without regard to environmental sustainability. ethnocentric and eurosentris (Parnell, 2011)

Criticism of modernization in post-mordern studies of post-colonial and related discussions relating to the problems of universal validity in various western institutions carries the implications and reorientation of critical and interperetative analysis of culture and social. This new practice involves, hears, and utilizes culture in scientific studies (Parnell, 2011). This new view which involves culture, leads to the recognition of different values and perspectives in social and cultural literature in the practice of western institutional education.

One of the ethnic groups with indigenous people who are able to maintain and uphold the traditions inherited from their ancestors, namely the indigenous people of Kampung Pulo located in Garut Regency, West Java Province. Kampung Pulo is located in an island-shaped area in the middle of a lake named Situ Cangkuang (Marliana, 2008) in (Ramdianti, Hidayah, \& Widiawati, 2013). Kampung Pulo was first built by Mbah Dalem Arief Muhammad in the 17th century (Hidajat, Fatharani, Martika, P, Fitria, \& Putih, 2014).

In the preliminary survey conducted by the researcher, accounting activities were not seen explicitly in the pulo customary community. The economic activities of indigenous peoples and the activities of the organization show clearly that accounting activities are actually involved in them, although under different names.

Economic activity shows the existence of activities related to finding income for survival by farming, trade, and 
services. This activity has been going on for hundreds of years since the 17th century (Hidajat et al., 2014).

Like accounting studies using social analysis (sociology) based on interpretive paradigms is an attempt to bring accounting knowledge closer to cultural, religious and spiritual realities (Mulawarman 2010 in Mahdalena 2016).

The purpose of this study is to find out more deeply the role of the environment based on cultural insights in the pulo indigenous community and to know more deeply the environmental accounting of responding culture as learning from the local culture of the pulo indigenous community.

\section{LITERATURE REVIEW}

\section{A. Environmental Accounting}

The concept of zero according to Bob Sadino means it means giving up hope. This means that each step without the lure, without creating important expectations, still acts and performs as a form of feeling grateful for what Allah has given. Zero is depicted as an empty circle, a manifestation of complete faith, resigned without prejudice and fear. Zero means "Total Surrender", a unanimous faith in what will happen in the future, belief in miracles and paths that we have never thought of at all (Setiabudi, 2015).

Environmental accounting is an effort of grouping costs by both private and government organizations in the framework of carrying out environmental conservation activities in the environmental post. These environmental conservation activities will emerge as costs to be borne by organizations both profit and non-profit organizations (Suartana, 2010).

Environmental accounting is analogous to a quantitative measurement of organizational performance associated with environmental conservation activities to the following activities: $\square$ The health of living things and the environment from pollution.

\section{- Global Warming}

- Environmental resources (Lindrianasari, 2007)

Because environmental accounting is associated with environmental and social concern for the organization, environmental accounting is known in the form of corporate social responsibility (CSR) and Sustainability Reprting (SR) (Suaryana, 2011). The assessment of the organization's concern for the environment and the measurement of organizational performance is known as the Global Reporting Index (GRI) (Suarsa \& Rinovian, 2018).

\section{B. Local Culture Based Environmental Accounting}

The implementation of environmental accounting as an organizational responsibility will be in contact with the local community and its culture. Involving local culture will increase the success of organizational performance in environmental accounting accountability reports (Gallhofer et al., 2000).

Research on environmental accounting that adapts Aboriginal cultures in Australia cuts into the colonialism of accounting. The absorption of culture in the practice of environmental accounting based on other research that discusses environmental accounting involving local culture in the indigenous peoples of the Anglo countries shows how the relationship between economic, social, and cultural activities in these societies. The study provides a description of the new literature in the world of accounting and its role in organizational management and empowerment of indigenous peoples so that accounting for cultural indigenous peoples is needed to provide protection for the environment and customs of Aboriginal people (Chew \& Greer, 1997).

Other research that discusses environmental accounting involving local culture in the indigenous peoples of Anglo countries shows how the relationship between economic, social, and cultural activities in these societies. The study provides a description of the new literature in the world of accounting and its role in organizational management and empowerment of indigenous peoples so that accounting is needed for indigenous peoples (Buhr, 2011).

Islamic law shows the principles of love for nature, for others, and for themselves. Mutual attention is the most important thing and is very reasonable so it creates a balance. Islamic culture in companies originating from Arabs operating in the UK shows how strong Islamic culture and values provide added value to companies in terms of social responsibility. This shows the integration between business processes and culture and Islamic values in the company (Kamla, Gallhofer, \& Haslam, 2006).

\section{The Role of Culture in Environmental Conservation}

Research on culture in environmental preservation has been carried out in Malay society which shows the relationship between humans and the close environment through culture. The culture of wandering is loaded with local karafan with environmental values especially in preserving the forest. The close association of Malay communities with the culture and natural surroundings can be seen from everyday life. They have a tradition of "abstinence prohibited" associated with preserving the environment (Thamrin, 2013).

Other research on environmental preservation based on culture can be seen from the life of the Baduy who are very dependent on nature. Local wisdom which is the culture of the Baduy in managing natural resources that always prioritizes the balance with nature can be seen from the rules of zoning into three parts, namely reuma (settlement), heuma (dry land and arable land), and leuweung kolot (old debt) zone. Customs are held firmly in maintaining balance (Suparmini, Setyawati, \& Sumunar, 2013).

Part of community culture is ritual, which plays an active role in environmental preservation. As a ritual tradition carried out in the village of Gunung Salak Girijaya, which means conservation, because it contains moral messages and invitations to do good and respect nature. In addition, the ritual also contains gratitude towards God Almighty for the abundant gifts from the produce of the earth. Likewise, humming that the community is singing is not only a spiritual satisfaction but a quiet song full of appreciation for nature (Royyani \& Walujo, 2012). 
From some of the studies above about the close relationship between culture and environmental preservation, then just as environmental accounting is a response to the organisation's concern for the environment, a deeper approach to culture will create added value for the presentation and reporting of environmental accounting.

\section{RESEARCH METHOD}

In this study, the method used is a qualitative method. A qualitative method with a phenomenological approach which is a constructivist or naturalistic approach (Fauji, Sudarma, \& Achsin, 2015). There are two fundamental reasons for the use of a qualitative approach in this study, namely: first, to explore and understand the meaning of the object of research from individuals or groups that are ascribed to social or humanitarian problems. Second, the acquisition of data can be more complete, more profound, and reliable, as well as all events in a social context that include feelings, norms, beliefs, habits, mental attitudes, and cultures adhered to by individuals and groups of individuals can be found (Creswell, 2010). The unit of analysis focuses on awareness, intuition, and intersubjectivity. The main data of this study are interviews and observations. Interviews were conducted with informants who truly understood and experienced the activities of the life of the indigenous people of Kampong Pulo as seen in table I.

TABEL I. INFORMAN LIST

\begin{tabular}{|c|c|c|}
\hline Number & Informan & Informantion \\
\hline 1. & Mr Umar & Deputy Pakuncen \\
\hline 2. & Mr Zaki & Direct descendants \\
\hline 3. & Ms Sri & Member of Indigenous People \\
\hline
\end{tabular}

Data credibility test is done by using triangulation techniques of interview results and through observation. And in the end a conclusion is drawn.

Research stages in this study include the following stages:

- Initial stage: researchers fully describe the phenomena experienced by research subjects. All records of the results of in-depth interviews with research subjects were transcribed into written language.

- Horizonalization Phase: from the results of transcription, researchers inventory important statements that are relevant to the topic. At this stage, the researcher must be patient to delay the assessment (bracketing / epoche); that is, the element of subjectivity should not interfere in the effort to detail important points, as research data, obtained from the results of the interview earlier.

- Cluster of Meaning Phase: Next, the researcher classifies the statements into themes or units of meaning, as well as setting aside overlapping or repetitive statements. At this stage, the following is done: (a) Textural description: The researcher writes what is experienced, namely a description of what the individual experiences; (b) Structural description: The writer writes how the phenomenon is experienced by individuals. The researcher also looks for all possible meanings based on the researchers own reflection, in the form of opinions, judgments, feelings, expectations of research subjects about the phenomena they experience.

- Essence description stage: researchers construct (construct) a comprehensive description of the meaning and essence of the experience of the subjects.
- Researchers report the results of their research. This report gives readers a better understanding of how a person experiences a phenomenon. The research report shows that there is a unity of meaning from experience, where all experiences have an important "structure".

\section{RESULT AND DISCUSSION}

\section{A. Environmental Accounting Based on Pamali}

The The environment in the perspective of the Kampong Pulo indigenous people is the main thing. As stated by Pakuncen representative "... ... the absolute environment is our concern and is part of our lives, the environment is not just a real environment but also includes an environment that cannot be felt by the senses, attention to the environment is to achieve balance ...", meaning that attention to the environment is also reflected in the rules that must not be violated, called Pamali. One of the pamali is that it is not allowed to maintain four-legged animals to prove that in the absence of such animals such as cows, buffaloes, the relatively small environment can guarantee its beauty and not dirty.

In everyday life there are no explicit financial statements, but forms of accountability are done in a simple note. "... we simply record what we receive for environmental preservation that comes from contributions from residents ..." said Pakuncen's representative. "... we have a lot of confidence in what Pakuncen and the citizens are doing in preserving the environment, and it is proven that the environment is still maintained ..." Sri said. Sri's statement is supported by the same statement by Mr. Zaki. Accountability is conveyed in spoken language at regular meetings.

The Role of Culture in Environmental Conservation

The environment has become a culture that is inherent in the members of indigenous peoples, the inherent culture is implied in ritual activities that are always carried out, for 
example, when starting to plant rice there is a mitembeyan ritual where the ritual of giving sasaji is a sign of permission and respect for invisible creatures.

Attention to plants / trees which are considered as living creatures and have a feeling of giving attention and tolerance to members of indigenous peoples. So that these activities have the effect of giving more attention to the maintenance of plants and trees.

Environmental preservation is also shown by preserving and maintaining the trees that provide life in their historical journey, for example they preserve the cangkuang tree as part of their life journey. Also the soeh tree which is a rare tree used for writing texts.

If it is related to environmental accounting which is a form of environmental stewardship which only shows more the organization's concern for the environment that is only measured by material, then indigenous peoples show culture more as a form of concern for environmental preservation.

Concern of indigenous community members towards the environment is a culture that is inherent in the soul, not only as an obligation but it is part of their soul to care for the environment.

From the behavior of the indigenous community of Kampong Pulo, if the red thread is drawn, the organizational paradigm is in the context of environmental stewardship by building a culture of community members who care about the environment. Culture of loving the built environment will be inherent in individuals who will automatically care for the environment.

\section{CONCLUSION}

From the research results above, it can be concluded as follows:

- From the behavior of the adat community of Kampong Pulo if a common thread is drawn that the organizational paradigm is in the context of environmental stewardship by building a culture of community members who care about the environment.

- The culture of loving the built environment will be inherent in individuals who will automatically care for the environmen

\section{ACKNOWLEDGMENTS}

We would like to thank the Directorate of Research and Community Service (DRPM), the Ministry of Research, Technology and Higher Education, Indonesia who has funded this research grant through a novice lecturer research scheme for the fiscal year 2019.

\section{REFERENCES}

11 Buhr, N. (2011). Indigenous peoples in the accounting literature: Time for a plot change and some Canadian suggestions. Accounting History, 16(2), 139-160. https://doi.org/10.1177/1032373210396334

[2] Chew, A., \& Greer, S. (1997). Contrasting world views on accounting: Accountability and Aboriginal culture. Accounting, Auditing \& Accountability Journal, 10(3), 276-298. https://doi.org/10.1108/09513579710178089

[3] Gallhofer, S., Gibson, K., Haslam, J., McNicholas, P., \& Takiari, B. (2000). Developing Environmental Accounting: Insights
From Indigenous Cultures. Accounting, Auditing \& Accounting $13(3)$ $381-409$. https://doi.org/10.1108/09513570010334937

[4] Hidajat, A., Fatharani, F., Martika, D., P, Fitria, A., \& Putih, G. (2014). Kajian Penggunaan Material Kayu dan Bambu Ditinjau Dari. Reka Karsa, 2(4), 1-10. https://doi.org/10.26760/rekakarsa.v2i4.615

[5] Kamla, R., Gallhofer, S., \& Haslam, J. (2006). Islam, nature and accounting: Islamic principles and the notion of accounting for the environment. Accounting Forum, 30(3), 245-265. https://doi.org/10.1016/j.accfor.2006.05.003

[6] Lindrianasari, L. (2007). Hubungan Antara Kinerja Lingkungan dan Kualitas Pengungkapan Lingkungan dengan Kinerja Ekonomi Perugahaan di Indonesia. Jurnal Akuntansi Dan Auditing Indonesia, 11(2), 159-172. Retrieved from http://www.jurnal.uii.ac.id/JAAI/article/view/218

[7] Niswatin, \& Mahdalena. (2016). Nilai Kearifan Lokal "Subak" Sebagai Modal Sosial Transmigran Etnis Bali. Jurnal Akuntansi Multiparadigma, $7(2), \quad 171-188$. https://doi.org/10.18202/jamal.2016.08.7015 Abstrak:

[8] Parnell, J. A. (2011). Article information: Journal of Advances in Management Research, 11, 232-256. https://doi.org/http://dx.doi.org/10.1108/MRR-09-2015-0216

[9] Ramdianti, N., Hidayah, H. A., \& Widiawati, Y. (2013). Kajian Etnobotani Mayarakat Adat Kampung Pulo di Kabupaten Garut. Majalah Ilmiah Biosfera, 30(1), 38-50. https://doi.org/10.20884/1.mib.2013.30.1.125

[10] Royyani, M. F., \& Walujo, E. B. (2012). P elestarian Lingkungan Berbasis Kepercayaan Lokal dan Upacara Tradisi : Studi Kasus Masyarakat di Sekitar Gunung Salak. Jurnal Biologi Indonesia, 8(1), 71-84. https://doi.org/10.14203/jbi.v8i1.3067

[11] Suarsa, A., \& Rinovian, R. (2018). Pengungkapan CSR Perbankan Syariah Sebagai Kebutuhan Informasi Stakeholder. Jurnal Ilmiah Manajemen Ekonomi Dan Akuntansi, 2(2), 179202.

[12] Suartana, I. W. (2010). Akuntansi Lingkungan Dan Triple Bottom Line Accounting: Paradigma Baru Akuntansi Bernilai Tambah. Jurnal Bumi Lestari, 10 Nomor 1, 105-112.

[13] Suaryana, A. (2011). Implementasi Akuntansi Sosial Dan Lingkungan. Jurnal Ilmiah Akuntansi Dan Bisnis, 6(1), 1-26. Retrieved https://ojs.unud.ac.id/index.php/jiab/article/view/2639

[14] Suparmini, Setyawati, S., \& Sumunar, D. R. S. (2013). Pelestarian Lingkungan Masyarakat Baduy Berbasis Kearifan Lokal. Jurnal Penelitian Humaniora, 18(1), 8-22.

[15] Thamrin, H. (2013). Kearifan Lokal dalam Pelestarian Lingkungan ( The Lokal Wisdom in Environmental Sustainable ). Kutubkhanah, 16(1), 46-59 